\title{
Development of a short-term memory capacity for escape training in neonatal $\mathrm{C} 3 \mathrm{H}$ mice*
}

\author{
Z. MICHAEL NAGY and JAMES M. MURPHY \\ Bowling Green State University, Bowling Green, Ohio 43403
}

$\mathrm{C} 3 \mathrm{H}$ mice received 25 training trials in a shock-escape straight alley at $5,7,8$, or 10 days of age, followed by an additional 25 trials $1 \mathrm{~h}$ later. Whereas all age groups demonstrated improvement in escape performance during both the training and retest sessions, evidence of retention of prior training did not appear until 7 days of age.

Several recent studies have provided evidence indicating that the development of an adult-like 24-h memory capacity for instrumental learning occurs around 9 days of age in rats and mice (Misanin, Nagy, Keiser, \& Bowen, 1971; Nagy, Misanin, Newman, Olsen, \& Hinderliter, 1972). Both species trained on a straight-alley shock-escape task at 9 days of age demonstrated retention effects of original training when retested 1,6 , or $24 \mathrm{~h}$ later. In contrast, neither species trained at 7 days of age evidenced retention effects when retested at either 6- or 24-h intervals following training, although both species demonstrated 1-h retention capacities. In addition, Swiss-Webster mice appeared to demonstrate 1 -h memory by 5 days of age (Nagy et al, 1972).

The present experiment was conducted to examine the age at onset of $1-h$ retention capacity of escape training in the $\mathrm{C} 3 \mathrm{H}$ mouse. Although previous research has shown that the age of onset of a 24-h retention capacity occurs at comparable ages in the $\mathrm{C} 3 \mathrm{H}$ and Swiss-Webster strains, the finding of a slightly earlier development of 6 -h retention capacity for the $\mathrm{C} 3 \mathrm{H}$ strain (Nagy, Misanin, \& Wetzel, in press) suggests the possibility of differences in early central nervous system maturation rates between the two strains which may also result in the earlier emergence of a 1 -h retention capacity in the $\mathrm{C} 3 \mathrm{H}$ strain.

\section{METHOD \\ Subjects}

The Ss were $80 \mathrm{C} 3 \mathrm{H}$ mice born and reared in $30.4 \times 18 \times$ $12.8 \mathrm{~cm}$ polyethylene cages with wire-grid tops and wood-chip shavings on the floor. Separate groups of 10 males and 10 females were tested at $5,7,8$, and 10 days of age, using a modified split-litter design. The mothers were on ad lib food and water and remained with the pups at all times except during testing sessions.

\section{Apparatus}

The apparatus consisted of a clear Plexiglas straight alley, 22.8 x $3.2 \times 6.4 \mathrm{~cm}$, with $1-\mathrm{mm}$-diam stainless steel rods centered $3 \mathrm{~mm}$ apart forming the grid floor. The rods were positioned parallel to the length of the alley. A removable Plexiglas door

\footnotetext{
* This research was supported by Research Grant GB-30456 from the National Science Foundation.
}

was placed $5 \mathrm{~cm}$ from one end, forming the startbox. A scrambled ac shock source (Harvard Instrument, Model H.I. 3121) provided a $1-\mathrm{mA} 60-\mathrm{Hz}$ current to the grid floor.

\section{Procedure}

At one of the appropriate ages, a mouse was removed from the litter, placed in the startbox, and oriented toward the goal end of the alley. After approximately $5 \mathrm{sec}$, the door was removed and shock initiated. When the $S$ reached within $5 \mathrm{~mm}$ of the goal end of the alley, the shock was terminated and the mouse removed from the apparatus and held in the E's closed hand for the 45-sec intertrial interval. Latencies from shock onset to offset were recorded from a running time meter to the nearest $.1 \mathrm{sec}$. If the mouse failed to reach the goal within $300 \mathrm{sec}$, it was gently forced to the goal and shock was terminated. Following training, the mouse was toe-clipped for identification and replaced in the home cage for the 1-h retention interval. Following the 1-h interval, an additional 25 trials were administered, employing procedures identical to original training. The number of competing responses (180-deg turns away from the goal) served as the principal performance measure (see Nagy et al, 1972, for discussion of appropriate learning measures for neonatal mice) for both the training and retest sessions.

\section{RESULTS AND DISCUSSION}

Figure 1 depicts the mean number of competing responses made over blocks of five trials for each age group during training and retest sessions. Age, sex, trial blocks, and test-retest were the factors considered in a 4 by 2 by 5 by 2 analysis of variance, the last two factors being repeated measures. The main effects of age $(F=$ $21.00, \mathrm{df}=3 / 72, \mathrm{p}<.0005)$, trial blocks $(\mathrm{F}=58.12, \mathrm{df}$ $=4 / 288, \mathrm{p}<.0005)$, and test-retest $(\mathrm{F}=13.94, \mathrm{df}=$ $1 / 72, p<.0005)$ proved to be significant. There were no significant interactions among factors, and sex was not reliable as a main effect. As is evident from the analysis and the graphical presentation in the upper right panel of Fig. 1, there was a reliable decrease in competing responses over age, which can be attributed to maturation. However, the reliable within-session decreases in competing responses over trial blocks suggest that $\mathrm{C} 3 \mathrm{H}$ mice are capable of increased inhibition of the competing response, resulting in improvement of the form of the escape response. Although the interaction between age and test-retest was not statistically reliable, a priori comparisons were conducted between the training and retest scores within each age group. The results indicated that the 5-day-old group did not differ in the number of competing responses made during training and retest sessions $(\mathrm{F}<1.00, \mathrm{df}=3 / 72)$, whereas the 7-, 8-, and 10-day-old groups made fewer competing responses during the retest sessions than during original training (all $F s \geqslant 3.43$, df $=3 / 72$, ps $<.025$ ).

Since there is the possibility, especially at short retention intervals, that factors other than memory may 


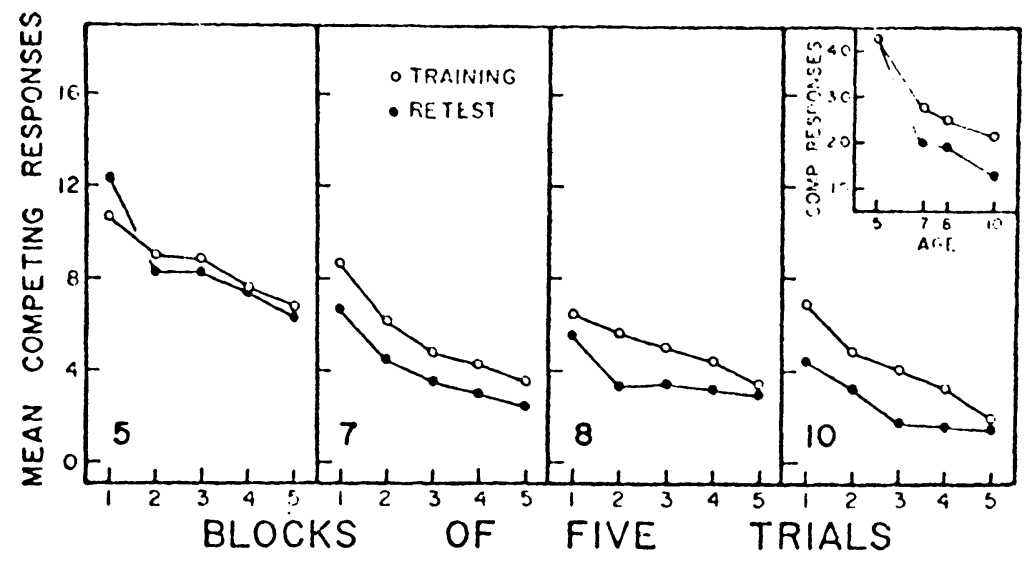

Fig. 1. Mean number of competing responses during training and retention sessions as a function of age.

account for the decrease in the number of competing responses made during the retest sessions, running speeds on trials without competing responses were compared during training and retest sessions. Factors such as fatigue, adaptation, and habituation might be expected to result in slower running speeds, whereas sensitization to shock should result in faster speed scores. A 4 by 2 by 2 analysis of variance was conducted on the mean reciprocal latencies for each mouse on trials without competing responses during training and retention sessions. Only the main effect for age proved significant $(\mathrm{F}=3.61, \mathrm{df}=3 / 72, \mathrm{p}<.025)$, again indicating changes in running speed due to maturational changes in motor ability. The failure to obtain differences in running speeds within ages between test and retest sessions supports the hypothesis that decreases in competing responses on retest sessions are reflecting memory of previously learned inhibition of that response for mice 7 days of age and older.

The results of the present study indicate that a 1-h retention capacity of an instrumentally learned response develops between 5 and 7 days of age in the $\mathrm{C} 3 \mathrm{H}$ mouse. Since the Swiss-Webster mouse appears capable of $1-\mathrm{h}$ retention of the escape task by 5 days of age (Nagy et al, 1972), these findings do not support a hypothesis of an earlier general maturation of central nervous system functions, or whatever the underlying basis of this short-term memory capacity, in $\mathrm{C} 3 \mathrm{H}$ mice as compared to Swiss-Webster mice. On the other hand, there remains the possibility of differential rates of maturation at different stages of development in the two strains, i.e., Swiss mice may develop more rapidly until 5.6 days of age, but then $\mathrm{C} 3 \mathrm{H}$ mice mature at a somewhat faster rate.

\section{REFERENCES}

Misanin, J. R., Nagy, Z. M., Keiser, E. M., \& Bowen, W. Emergence of long-term memory in the neonatal rat. Journal of Comparative \& Physiological Psychology, 1971, 77. 188-199.

Nagy, Z. M., Misanin, J. R., Newman, J. A., Olsen, P. L., \& Hinderliter, C. F. Ontogeny of memory in the neonatal mouse. Journal of Comparative \& Physiological Psychology, 1972, 81, 380-393.

Nagy, Z. M., Misanin, J. R., \& Wetzel, B. Inception of a 24-h memory capacity in two mouse strains. Developmental Psychobiology, in press.

(Received for publication September 10, 1973.) 